\title{
A comparison of Italian ryegrass (Lolium multiflorum) cultivars Exalta and Midmar with respect to their nutritive value for sheep
}

\author{
H.H. Meissner* \\ Department of Animal and Wildlife Sciences, University of Pretoria, Pretoria, 0002 Republic of South Africa
}

Rceived 17 August 1995; accepted 20 February 1996

\begin{abstract}
The nutritive value of Exalta was compared with Midmar in a grazing trial with lambs and in a digestion trial with mature wethers. The study was conducted between 17 August and 8 October 1993. Fifteen lambs per cultivar grazed the pastures using a two paddock per cultivar rotation procedure. Intake was measured from IVDOM of oesophageal samples and $\mathrm{OM}$ excreted as collected by faecal bag. Lambs were weighed regularly and wool production was measured from a $100 \mathrm{~cm}^{2}$ patch on the right mid-rib area. In the digestion trial, fermentation endproducts and nutrient disappearance in the gut were measured through multiple cannulae using $\mathrm{Yb}$-acetate and $\mathrm{Cr}$-EDTA as markers. Five sheep were used per cultivar; they were fed freshly cut ryegrass at four equally spaced intervals in $24 \mathrm{~h}$. In both trials, DM content of the herbage exceeded $18 \%$ so high moisture content should not have limited forage intake. Cell wall content was more often lower for Exalta than for Midmar, the difference being primarily due to cellulose. In contrast, TNSC contents were more often higher. Other constituents did not differ significantly. OM intakes did not differ significantly between cultivars, being 80.2 and $84.3 \mathrm{~g} \mathrm{OM} /$ $\mathrm{kgW}^{0.75} / \mathrm{d}$ for Exalta in the grazing and digestion trial respectively, and 76.1 and $79.1 \mathrm{~g} \mathrm{OM} / \mathrm{kgW}^{0.75} / \mathrm{d}$ for Midmar. ADG in the grazing trial did not differ significantly, $239 \mathrm{~g} / \mathrm{d}$ for Exalta and $224 \mathrm{~g} / \mathrm{d}$ for Midmar, but clean wool yield was highly significantly lower for lambs grazing Exalta $\left(21.0 \mathrm{vs} 34.4 \mathrm{~g} / 100 \mathrm{~cm}^{2}\right)$. None of the rumen fermentation parameters or nutrients which disappeared in the gut differed significantly, except CP where $86 \%$ of CP intake disappeared postruminally on Exalta versus only $62 \%$ on Midmar. The higher TNSC contents of Exalta presumably enhanced microbial protein production in the rumen and thereby promoted higher protein flow to the small intestine. However, wool production results were opposite to that expected from protein supply only.
\end{abstract}

Keywords: Ryegrass, Exalta, Midmar, nutritive value, sheep

*Current address: Animal Nutrition and Animal Products Institute, Private Bag X2, Irene, 1675 Republic of South Africa

\section{Introduction}

The Italian ryegrass cultivar Midmar is extensively cultivated in South Africa. Although it is well-adapted and DM yields are satisfactory, animal performance is often disappointing. Reasons are high nitrate-N (De Villiers \& Van Ryssen, 1991), low DM content (Meissner et al., 1992), high ash contents (Meissner \& Paulsmeier, 1995) and probably an imbalance between $\mathrm{N}$ and energy (e.g. low total non-structural carbohydrate (TNSC) content), resulting in low OM intake and inadequate microbial protein synthesis (Aii \& Stobbs, 1980). Du Preez and Meissner (1992) concluded that if the DM content of Midmar is above $18-20 \%$, amino acid absorption from the small intestine should be optimal for Midmar.

The question remains, however, whether microbial protein production and therefore total protein passage to the small intestine cannot be increased if the $\mathrm{N}$-energy ratio in the plant is improved. A selection programme instituted at the Cedara Research Station addresses this and other issues. The cultivar Exalta, for example, contains higher concentrations of DM and TNSC at comparable growth stages than Midmar (Marais, 1993) and the selection programme to increase these constituents has not affected adversely the cell wall composition and digestibility of the grass (Marais et al., 1995). Thus, if the higher TNSC contents are favourable to microbial protein production, and other factors such as amino acid composition are not different, animal performance should benefit. In the present investigation we therefore compared Exalta with Midmar with respect to lamb growth and wool production, as well as the disappearance in the lower digestive tract of protein and other constituents. To minimize the effect of other factors, the study was conducted when the DM content of the cultivars was at least $18 \%$.

\section{Materials and Methods \\ Grazing trial}

\section{Pastures}

Midmar and Exalta were established in two replicates on a Hutton soil during April 1993. The University of Pretoria Experimental Farm (Hatfield) has an exclusively summer rainfall of $650 \mathrm{~mm}$ per annum, a dry autumn and winter and an altitude of $1950 \mathrm{~m}$. Daily winter temperatures are mild but frost occurs frequently at night. Nitrogen fertilizer was applied at a level of $150 \mathrm{~kg} / \mathrm{ha}$ at date of planting and $100 \mathrm{~kg}$ $\mathrm{N} /$ ha in July 1993. Potassium and P were not applied as soil analysis indicated adequate levels. Pastures were irrigated every week to an equivalent of $15 \mathrm{~mm}$.

\section{Grazing management and measurements on pasture}

Grazing commenced in August 1993. Fifteen Mutton Merinotype lambs with initial mass of $27.5 \pm 2.6 \mathrm{~kg}$ were allocated per cultivar and allowed to graze the pastures between 17 August and 8 October 1993. The lambs grazed the two replicate paddocks at random depending upon irrigation sequence and the availability of grazing material. Availability was set at $2.5 \mathrm{~kg} \mathrm{DM}$ per lamb per day (quadrat method) to standardize grazing pressure between Exalta and Midmar and between paddock replicates. Lamb movement was controlled by electric fence.

Five of the 15 lambs per cultivar were identified to receive faecal bags for intake studies. Faeces were collected during 
the weeks of 25 August, 6 September, 20 September and 4 October 1993. To prepare the lambs for faecal collection, faecal bags were fitted three days before. At this time also, they were cleaned and shorn at the buttock area and between the hind legs. To prevent parasite infestation, lambs were dosed with antihelmintics monthly and with external disinfectants at the buttock area if necessary.

All 15 lambs per cultivar were used for daily gain and wool growth measurements. The five per cultivar that were used for faecal collection were initially treated separately in the statistical analysis, but pooled with the others later because their results were not statistically different. Wool growth and mass gains (ADG) were measured between 15 August and 10 October 1993. The wool sample was obtained from a $100 \mathrm{~cm}^{2}$ patch on the right mid-rib area. Wool yield on the patch was measured for the same period.

For pasture quality determination, both hand-clipped and oesophageal samples were collected. Samples were collected by hand when the electric fence was moved, i.e. every 4-5 days. This was necessary to ensure the set $2.5 \mathrm{~kg}$ DM per lamb per day. Oesophageal samples were obtained at the beginning and end of every faecal collection period, i.e. four collection periods times two samples between 25 August and 8 October 1993. For that purpose, three adult sheep per cultivar fitted with oesophageal fistulas were introduced to the pasture. They were run with the lambs from three days before the week of faecal collection, but withdrawn from pasture between collection periods to avoid affecting the grazing pressure. Oesophageal samples were taken after a $6 \mathrm{~h}$ fast.

\section{Analyses of samples in grazing trial}

Oesophageal extrusa was lightly strained through cheesecloth and then freeze-dried together with hand-harvested samples. Samples were then milled through a $2 \mathrm{~mm}$ screen before being analysed for DM, ash, $\mathrm{N}$ (Kjeldahl), neutral detergent fibre (NDF) (Van Soest \& Wine, 1967), acid detergent fibre (ADF) and acid detergent lignin (ADL), and TNSC (Marais, 1979).

Hemicellulose was assumed to be the difference between NDF and ADF and cellulose the difference between ADF and ADL. Crude protein (CP) was calculated as $\mathrm{N} \times 6.25$.

In vitro digestibility of organic matter (IVDOM) was determined by the modification of Engels et al. (1981) to the Tilley \& Terry (1963) technique. Faecal samples were oven-dried $\left(60^{\circ} \mathrm{C}\right)$ and milled as above before being ashed to determine $\mathrm{OM}$ content. Intake of $\mathrm{OM}$ was then calculated as the ratio between the OM excreted per day and the indigestible $O M$ portion as calculated from the IVDOM.

Wool samples were cleaned by washing successively in a commercial laundry detergent $(10 \mathrm{~g} / 1$ water $)$ and rinsing in clean water until the effluent was clear. Washed samples were dried at $105^{\circ} \mathrm{C}$. Wool growth was expressed as clean wool yield per $100 \mathrm{~cm}^{2}$ patch.

\section{Digestion trial}

Five mature Mutton Merino-type wethers $(60 \pm 3.5 \mathrm{~kg}$ ) per cultivar were fistulated in the rumen, abomasum and terminal ileum and kept in metabolism cages in a well-ventilated room from 25 August to 20 September 1993. They were fed $a d$ lib, freshly cut pasture material, divided into four equal portions, at $06 \mathrm{~h} 00,12 \mathrm{~h} 00,18 \mathrm{~h} 00$ and $00 \mathrm{~h} 00$. To facilitate feeding and to limit wastage, the fresh herbage was chopped into $5-10 \mathrm{~cm}$ pieces before being fed, and orts were collected and weighed before the $06 \mathrm{~h} 00$ feeding. Intake was measured between 9 and 20 September 1993, faecal bags were fitted on 9 September and collection plus marker infusion into the rumen started on 12 September. Digesta samples were collected from the rumen, abomasum, ileum and rectum using a $24 \mathrm{~h}$ simulated programme over four days. These collections plus faecal collections ended on the morning of 20 September 1993.

Markers were ytterbium ( $\mathrm{Yb}$ ) acetate as solids marker and the complex of chromium with ethylenediamine tetra-acetic acid (Cr-EDTA) as liquid phase marker (Siddons et al., 1985). A primer dose was administered on 12 September whereafter markers were continuously infused until 16 September when digesta sampling started, and further kept up until 20 September when the trial ended. The two markers were administered via separate infusion lines to prevent precipitation of Yb-acetate. Infusion rates were $180 \mathrm{mg} /$ day/ sheep for Cr-EDTA and $120 \mathrm{mg} /$ day/sheep for $\mathrm{Yb}$-acetate, respectively. Chromium-EDTA was prepared according to the method of Binnerts et al. (1968) and Yb-acetate by dissolving the required quantity in distilled water (Siddons $\mathrm{et}$ al., 1985).

Herbage and faecal samples were collected daily and pooled for analysis. Pooled herbage samples were freezedried and faecal samples oven-dried at $60^{\circ} \mathrm{C}$. All dried samples were milled through a $2-\mathrm{mm}$ screen and subsequently analysed for DM, ash, N, NDF, ADF and ADL to enable calculation of constituent digestibility. Only herbage samples were analysed for TNSC as it was assumed that TNSC would be $100 \%$ digestible. The IVDOM of herbage was also determined.

Ytterbium and $\mathrm{Cr}$ were analysed by atomic absorption spectrometry after extraction by the methods described by Siddons et al. (1985). The double marker reconstitution method of Faichney (1980) was used to calculate liquid and solids passage and the latter checked by ADL which proved to be close to $100 \%$ indigestible (see Table 4). Rumen $\mathrm{pH}$ and samples for ammonia $\left(\mathrm{NH}_{3}\right) \mathrm{N}$ were collected at the same times as the samples to determine passage. Rumen $\mathrm{NH}_{3}-\mathrm{N}$ was determined by auto-analyser after storage in $\mathrm{H}_{2} \mathrm{SO}_{4}$ in a freezer.

\section{Statistical analyses}

Hand-harvested and oesophageal sample constituents as well as OM intake in the grazing trial were analysed by ANOVA with cultivar and period (dates) as variables. Wool yield for the period and ADG were only analysed for cultivar differences. Because of irregular sampling dates and therefore empty cells, cultivar and period differences were tested by Bonferroni (SAS, 1985) rather than Tukey's studentised range test. In the digestion trial, differences between cultivars were tested by one-way analysis of variance and Tukey's $t$ test. The $5 \%$ level of probability was in all cases accepted as the appropriate indication of a significant result.

\section{Results and Discussion}

The composition of Exalta and Midmar in the grazing trial as obtained from both hand-clipped and oesophageal samples, is 
given in Table 1. That of the digestion trial is shown in Table 2 .

Dry matter content of Exalta and Midmar in the grazing trial was similar and just above $18 \%$. Period effects and period $\times$ cultivar interaction were, however, significant. The DM content of Exalta was about $20 \%$ in late August 1993, $15 \%$ for the first two weeks of September and $18.5 \%$ thereafter. The DM contents of Midmar, in contrast, changed from

Table 1 Composition of Exalta and Midmar in the grazing trial

\begin{tabular}{lccc}
\hline Hand-harvested samples & Exalta & Midmar & PR $\geq \mathrm{F}$ \\
\hline DM, \% & 18.1 & 18.3 & 0.627 \\
\% in DM:OM & 88.2 & 88.6 & 0.582 \\
Ash & 11.8 & 11.4 & 0.594 \\
CP & 17.3 & 17.4 & 0.888 \\
NDF & $41.4^{\mathrm{a}}$ & $43.1^{\mathrm{b}}$ & 0.025 \\
ADF & $21.0^{\mathrm{a}}$ & $23.3^{\mathrm{b}}$ & 0.001 \\
ADL & 4.10 & 3.60 & 0.151 \\
Cellulose & $16.9^{\mathrm{a}}$ & $19.7^{\mathrm{b}}$ & 0.001 \\
Hemicellulose & 20.4 & 19.8 & 0.225 \\
TNSC & 15.0 & 15.2 & 0.827 \\
IVDOM & 82.5 & 82.2 & 0.684 \\
Oesophageal samples & & & \\
\% in DM:OM & 86.2 & 85.6 & 0.085 \\
Ash & 13.8 & 14.5 & 0.085 \\
CP & 20.1 & 21.5 & 0.137 \\
NDF & 41.3 & 42.8 & 0.545 \\
ADF & 22.2 & 23.5 & 0.405 \\
ADL & 5.37 & 5.07 & 0.615 \\
Cellulose & 16.9 & 18.5 & 0.337 \\
Hemicellulose & 19.1 & 19.3 & 0.851 \\
TNSC & 8.61 & 5.62 & 0.061 \\
IVDOM & 81.5 & 81.2 & 0.653 \\
\hline
\end{tabular}

$\overline{a, b}$ Figures in the same line with different superscripts differ significantly

Table 2 Composition of Exalta and Midmar in the digestion trial

\begin{tabular}{lccc}
\hline & Exalta & Midmar & PR $\geq F$ \\
\hline DM, \% & $19.4^{\mathrm{a}}$ & $21.2^{\mathrm{b}}$ & 0.004 \\
\% in DM:OM & 88.7 & 87.9 & 0.342 \\
Ash & 11.3 & 12.1 & 0.342 \\
CP & 14.5 & 16.6 & 0.087 \\
NDF & 43.1 & 44.3 & 0.331 \\
ADF & $23.0^{\mathrm{a}}$ & $24.9^{\mathrm{b}}$ & 0.014 \\
ADL & 3.35 & 3.37 & 0.970 \\
Cellulose & 19.6 & 21.6 & 0.069 \\
Hemicellulose & 20.1 & 19.3 & 0.298 \\
TNSC & $15.6^{\mathrm{b}}$ & $13.0^{\mathrm{a}}$ & 0.022 \\
IVDOM & 83.5 & 82.8 & 0.505 \\
\hline
\end{tabular}

${ }^{a, b}$ Figures in the same line with different superscripts differ significantly
$18.5 \%$ between 17 and 24 August to $14.5 \%$ between 27 August to 10 September and then increased to about $20 \%$ towards the end of September. The latter difference in DM content between Exalta and Midmar is reflected in the digestion trial (Table 2) which was conducted after 15 September 1993. In both trials, however, DM content averaged above $18 \%$ as intended and as a result $\mathrm{OM}$ intake in both trials was close to maximum ( 83 to $90 \mathrm{~g} / \mathrm{kg} \mathrm{W}^{0.75} / \mathrm{day}$ ) as reported by Meissner et al. (1992) and predicted by Meissner and Paulsmeier (1995).

Compositional differences between Exalta and Midmar in the grazing trial generally were small and not significant (Table 1). Period differences usually were larger and, as with DM content, period $\times$ cultivar interaction sometimes was significant. For hand-clipped samples, NDF, ADF and cellulose were significantly less in Exalta than Midmar, but these differences were not significant in oesophageal samples. The difference in cell wall constituents again occurred in the digestion trial (Table 2), where the difference in ADF content was significant and that of cellulose approached significance $(p \leq 0.069)$. It does appear that cellulose content of Exalta is responsible for the lower cell wall contents compared to Midmar, as hemicellulose and ADL contents did not differ significantly in any comparison (Tables 1 and 2). In general, the compositional results confirm that selection for TNSC has not affected cell wall contents and grass digestibility negatively (Marais et al., 1995). In fact, some aspects may be more favourable in Exalta than in Midmar.

TNSC contents did not differ significantly between cultivars in the hand-clipped samples of the grazing trial (Table 1). The difference approached significance in the oesophageal samples $(p \leq 0.061)$ and was significant in the hand-clipped samples of the digestion trial. The higher TNSC contents of Exalta shown here (Table 2) agree with the reports of Marais (1993) and Marais et al. (1995). These authors indicated that TNSC contents are greatly affected by sunlight and temperature and therefore the time of day when samples are collected. Although both hand-clipped and oesophageal samples were collected in the morning, it was not possible to synchronize collection times exactly. This could have contributed to the difference in TNSC between hand-clipped and oesophageal samples. In addition, it is possible that the soluble TNSC may be lost partially from the oesophageal samples when the samples were strained through cheesecloth.

As suggested with DM contents, the herbage fed in the digestion trial was somewhat more mature than the herbage grazed by the lambs. This is reflected in the lower CP and higher cell wall contents of the fed herbage (Table 2). In vitro DOM was, however, not lower which is consistent with previous findings (Meissner et al., 1991; 1992). This results because the cell wall digestibility of ryegrass does not decrease appreciably with ageing. The values of 81 to $83 \%$ IVDOM are furthermore consistent with the 79 to $82 \%$ reported by Meissner et al. (1992).

The OM intake, daily gain and wool growth of the lambs at pasture are displayed in Table 3. Intake of OM and ADG were not significantly different between cultivars, although the results of Exalta tended to be higher. Clean wool percentage was similar but clean wool yield was highly significantly $(p \leq 0.0001)$ superior for Midmar. With time, OM intake 
Table 3 Intake, ADG and wool production of lambs grazing Exalta and Midmar pastures

\begin{tabular}{lccc}
\hline & Exalta & Midmar & PR $\geq F$ \\
\hline OM intake, g/day & 1278 & 1202 & 0.255 \\
OM intake, g/kg W $0.75 /$ day & 80.2 & 76.1 & 0.323 \\
Week 1: 25-30/08/93 & $68.0_{1}$ & $78.7_{1,2}$ & - \\
Week 1: 06-10/09/93 & $78.8^{\mathrm{b}}{ }_{1}$ & $61.81^{\mathrm{a}}{ }_{1}$ & - \\
Week 3: 20-25/09/93 & $90.1_{2}$ & $83.7_{2}$ & - \\
Week 4: 04-08/10/93 & $83.9_{1,2}$ & $80.4_{2}$ & - \\
ADG, g/day & 239 & 224 & 0.177 \\
Clean wool, \% & 65.1 & 66.0 & 0.501 \\
Clean wool yield, g/100 cm ${ }^{2}$ & $21.0^{\mathrm{a}}$ & $34.4^{\mathrm{b}}$ & 0.0001 \\
\hline
\end{tabular}

a,b Figures in the same line with different superscripts differ significantly

1,2 Figures in the same column with different subscripts differ significantly

increased significantly coinciding partially with DM content. For example, the DM contents of Exalta and Midmar were 14 to $15 \%$ in the second week of intake determination resulting in comparatively low intakes. High ash contents may have been a further factor contributing to low intake as reported by Meissner \& Paulsmeier (1995). During the first week of intake measurement, the ash content of Exalta was $>14 \%$ compared to the overall average of $11.8 \%$ and in the second week $14 \%$ for Midmar compared to the overall average of $11.4 \%$ (Table 1). Soil contamination because of irrigation would have contributed to these high ash contents at this stage, because the herbage canopy was not yet closed.

Intake in the digestion trial (Table 4) did not differ significantly between Exalta and Midmar but appeared to be marginally higher than in the grazing trial. This may be explained partially by the higher DM content of the herbage in the

Table 4 Intake and apparent digestibilities of Exalta and Midmar in the digestion trial

\begin{tabular}{lccc}
\hline & Exalta & Midmar & $\mathrm{PR}>\mathrm{F}$ \\
\hline OM intake, g/day & 1845 & 1709 & 0.254 \\
OM intake, g/kg W O.75/day $^{-}$ & 84.3 & 79.1 & 0.310 \\
Constituent intake: CP, g/day & 294 & 323 & 0.179 \\
NDF, g/day & 899 & 864 & 0.536 \\
ADF, g/day & 479 & 487 & 0.803 \\
ADL, g/day & 69.9 & 65.8 & 0.349 \\
Cellulose, g/day & 410 & 421 & 0.683 \\
Hemicellulose, g/day & 420 & 377 & 0.113 \\
TNSC, g/day & $327^{\mathrm{b}}$ & $254^{\mathrm{a}}$ & 0.003 \\
Digestibility of: OM, \% & 86.7 & 85.9 & 0.450 \\
CP, \% & 79.4 & 81.8 & 0.077 \\
NDF, \% & 87.6 & 86.1 & 0.209 \\
ADF, \% & 82.5 & 83.1 & 0.708 \\
ADL, \% & -3.86 & 0.09 & 0.575 \\
Cellulose, \% & 97.3 & 96.2 & 0.387 \\
Hemicellulose, \% & $93.3^{\mathrm{b}}$ & $89.9^{\mathrm{a}}$ & 0.005 \\
\hline
\end{tabular}

${ }^{a, b}$ Figures in the same line with different superscripts differ significantly digestion trial (Table 2). Intake of other constituents, apart from TNSC, also did not differ significantly between cultivars. The higher TNSC intake of Exalta was due to a higher TNSC content (Table 2). The digestibility of OM and other constituents did not differ significantly between cultivars. The exception was hemicellulose digestibility where the figure for Exalta was higher $(p \leq 0.005)$ (Table 4). ADL digestibility did not differ significantly from zero. Recovery of ADL in the faeces was $104 \% \pm 5.5 \%$ for Exalta and $100 \pm 9.7 \%$ for Midmar; and therefore, ADL was used as a marker to check solids passage through the digestive tract.

In vivo digestibilities of $\mathrm{OM}, \mathrm{CP}$ and cell wall constituents were similar to in vivo figures of previous investigations. For example, $\mathrm{OM}$ and $\mathrm{CP}$ digestibilities in the present trials were about 86 and $80 \%$, respectively (Table 4 ). In the trials of Meissner et al. (1992), OM digestibility varied between 84 and $85.6 \%$ and in the trial of Du Preez \& Meissner (1992) OM digestibility ranged from 84.7 to $85.4 \%$. In the latter investigation CP digestibility ranged between 78 and $80.5 \%$.

Rumen $\mathrm{pH}$ and $\mathrm{NH}_{3}-\mathrm{N}$ did not differ significantly between cultivars (Table 5). Similar $\mathrm{NH}_{3}-\mathrm{N}$ concentrations probably reflect similar ruminal degradation of $\mathrm{CP}$ of the two cultivars. Du Preez \& Meissner (1992) reported an effective CP degradation at a fractional outflow rate of $0.05 / \mathrm{h}$ of $78 \%$ with a concomitant rumen $\mathrm{NH}_{3}-\mathrm{N}$ level of $15.9 \mathrm{mmol} / \mathrm{l}$ which is about $15 \%$ lower than the present; that despite a higher herbage CP content of $18.5 \%$. By way of deduction, one could expect an effective degradation of about $80 \%$ and a higher soluble $\mathrm{N}$ fraction for Exalta and Midmar in the present trial.

Apart from $\mathrm{CP}$, the disappearance of $\mathrm{OM}$ and the other constituents as a percentage of intake, did not differ significantly between cultivars (Table 5 ). Less CP apparently disappeared in the rumen of lambs on Exalta $(p \leq 0.066)$ and more in the large intestine $(p \leq 0.012)$ in comparison to Midmar. A similar numerical result was evident in the small intestine, although the difference was not significant $(p \leq 0.141)$. Because of relatively large errors in passage measurements, part of the disappearance in the large intestine may have occurred in the small intestine. For NDF, these associated errors estimated a negative disappearance for NDF in the small intestine and therefore disappearance of NDF and other cell wall constituents were rather considered together for the small and large intestine. If the negative disappearance is corrected, more $\mathrm{CP}$ would have disappeared in the small intestine and less in the large intestine and the difference between cultivars in the small intestine could have become significant. In total, $254 \mathrm{~g} \mathrm{(86 \%} \mathrm{of} \mathrm{CP}$ intake) disappeared in the lower digestive tract on Exalta and $202 \mathrm{~g}(62 \%$ of $\mathrm{CP}$ intake) on Midmar which is substantial.

The higher TNSC levels in Exalta compared to Midmar, may have improved microbial protein production and protein passage to the small intestine. This might increase intake, lamb growth and wool production if postruminal protein supply is inadequate. Wool production, however, was higher on Midmar (Table 3) which is puzzling. A plausible explanation for this apparent anomaly may be poor randomization between lambs. Lambs in the grazing trial were blocked for initial mass but not for wool production, and being a Mutton Merino-type with large variation in wool production potential, those with the higher potential could have been allotted 
Table 5 Disappearance of constituents in the digestive tract of sheep fed Exalta or Midmar (digestion trial)

\begin{tabular}{|c|c|c|c|}
\hline Organ & Exalta & Midmar & $\mathrm{PR} \geq \mathbf{F}$ \\
\hline Rumen: $\quad \mathrm{pH}$ & 5.87 & 5.85 & 0.922 \\
\hline $\mathrm{NH}_{3}-\mathrm{N}, \mathrm{mmol} / \mathrm{l}$ & 17.6 & 19.0 & 0.344 \\
\hline $\mathrm{OM}, \mathrm{g} / \mathrm{day}$ & 898 & 887 & 0.916 \\
\hline$\%$ of intake & 48.8 & 52.2 & 0.553 \\
\hline $\mathrm{CP}, \mathrm{g} /$ day & -18.3 & 62.2 & 0.056 \\
\hline$\%$ of intake & -6.00 & 19.4 & 0.066 \\
\hline NDF, g/day & 761 & 705 & 0.145 \\
\hline$\%$ of intake & 84.6 & 81.9 & 0.329 \\
\hline $\mathrm{ADF}, \mathrm{g} /$ day & 386 & 378 & 0.701 \\
\hline$\%$ of intake & 80.6 & 78.0 & 0.337 \\
\hline Cellulose, g/day & 387 & 378 & 0.672 \\
\hline$\%$ of intake & 94.4 & 90.1 & 0.185 \\
\hline Hemicellulose, g/day & $375^{\mathrm{b}}$ & $327^{\mathrm{a}}$ & 0.018 \\
\hline$\%$ of intake & 89.2 & 87.1 & 0.544 \\
\hline \multicolumn{4}{|l|}{ Small intestine: } \\
\hline OM, g/day & 404 & 337 & 0.549 \\
\hline$\%$ of intake & 21.8 & 19.6 & 0.692 \\
\hline $\mathrm{CP}, \mathrm{g} / \mathrm{day}$ & 210 & 174 & 0.352 \\
\hline$\%$ of intake & 71.1 & 53.6 & 0.141 \\
\hline \multicolumn{4}{|l|}{ Large intestine: } \\
\hline OM, g/day & 236 & 164 & 0.066 \\
\hline$\%$ of intake & 12.8 & 9.48 & 0.098 \\
\hline CP, g/day & $44.1^{\mathrm{b}}$ & $28.3^{a}$ & 0.036 \\
\hline$\%$ of intake & $15.0^{\mathrm{b}}$ & $8.76^{\mathrm{a}}$ & 0.012 \\
\hline \multicolumn{4}{|l|}{ Small and large intestine: } \\
\hline NDF, g/day & 30.6 & 38.0 & 0.797 \\
\hline$\%$ of intake & 2.76 & 4.10 & 0.646 \\
\hline $\mathrm{ADF}, \mathrm{g} /$ day & 12.6 & 26.9 & 0.443 \\
\hline$\%$ of intake & 2.65 & 5.22 & 0.455 \\
\hline Cellulose, g/day & 12.5 & 27.0 & 0.439 \\
\hline$\%$ of intake & 3.09 & 6.09 & 0.455 \\
\hline Hemicellulose, g/day & 18.1 & 15.1 & 0.833 \\
\hline$\%$ of intake & 4.30 & 3.59 & 0.828 \\
\hline
\end{tabular}

${ }_{a, b}$ Figures in the same line with different superscripts differ significantly

coincidentally to Midmar. It is also possible that nutrients not measured might have differed. Preliminary results (Acheampong-Boateng \& Meissner, unpublished) indicate pasture differences in amino acid composition and absorption in the small intestine of sheep.

\section{Acknowledgements}

The author wishes to express his sincere appreciation to Dagmar Paulsmeier, Heleen Heydenrych and the Nutrition
Science Honours students of 1993 for technical assistance. The financial assistance of the ARC (Veld and Forage Institute) is also acknowledged.

\section{References}

AII, T. \& STOBBS, T.H. 1980 . Solubility of the protein of tropical pasture species and the rate of its digestion in the rumen. Anim. Feed Sci. Tech. 5, 183.

BINNERTS, W.T., VAN'T KLOOSTER, A. \& Th FRENS, A.M. 1968. Soluble chromium indicator measured by atomic absorption in digestion experiments. Vet. Rec. 82, 470.

DE VILLIERS, J.F. \& VAN RYSSEN, J.B.J. 1991. The effect of nitrogen fertilization of Italian ryegrass on the performance of sheep. In: Proc. 30th Annual Congress SASAS, March 1991, Port Elizabeth.

DU PREEZ, M.M. \& MEISSNER, H.H., 1992. Utilization of Lolium multiflorum by sheep. 2 . The effect of drying the herbage on soluble nitrogen content and partial digestion. J. Grassl. Soc. South. Afr. 9, 18.

ENGELS, E.A.N., DE WAAL, H.O., BIEL, L.C. \& MALAN, A. 1981. Practical implications of the effect of drying and treatment on nitrogen content and in vitro digestibility of samples collected by oesophageally fistulated animals. S.Afr. J. Anim. Sci. 11, 247.

FAICHNEY, G.J. 1980. Measurement in sheep of the quantity and composition of rumen digesta and of the fractional outflow rates and digesta constituents. Aust. J. Agric. Res. 31, 1129.

MARAIS, J.P. 1979. Evaluation of acid hydrolysis procedures for the rapid determination of total non-structural carbohydrates in plant species. Agrochemophysica. 11, 1.

MARAIS, J.P. 1993. Dry matter and nonstructural carbohydrate content as quality parameters in a Lolium multiflorum breeding programme. In: Proc. 28th Annual Congress GSSA, January 1993, Bloemfontein.

MARAIS, J.P., DE FIGUEREDO, M. \& GOODENOUGH, D.C.W. 1995. Selection for high dry matter and nonstructural carbohydrate content in Lolium multiflorum: Effect on other nutritive quality parameters. In: Proc. 30th Annual Congress GSSA, January 1995, Kroonstad.

MEISSNER, H.H., DU PREEZ, M.M., ENSLIN, A.D. \& SPREETH, E.B., 1992. Utilization of Lolium multiflorum by sheep. 1. Influence of dry matter content and correlated factors on voluntary intake. J. Grassl. Soc. South Afr. 9, 11.

MEISSNER, H.H., KÖSTER, H.H., NIEUWOUDT, S.H. \& COERTZE, R.J. 1991. The effect of energy supplementation on intake and digestion of early and mid-season ryegrass and Panicum/Smuts finger hay, and on in sacco disappearance of various forage species. S.Afr. J. Anim. Sci. 21, 33.

MEISSNER, H.H. \& PAULSMEIER, D.V. 1995. Plant compositional constituents affecting between-plant and animal species prediction of forage intake. J. Anim. Sci. 73, 2447.

SAS User's Guide, 1985. SAS Institute Inc. Raleigh, North Carolina.

SIDDONS, R.C., PARADINE, J., BEEVER, D.E. \& CORNELL, P.R. 1985. Ytterbium acetate as a particulate-phase digesta-flow marker. Br. J. Nutr. 54, 509.

TILLEY, J.M.A. \& TERRY, R.A., 1963. A two-stage technique for the in vitro digestion of forage crops. J. Br. Grassl. Soc. 18, 104.

VAN SOEST, P.J. \& WINE, R.H., 1967. Use of detergents in analysis of fibrous feeds. 4. Determination of plant cell wall constituents. J. Assoc. Off. Agric. Chem. 50, 50. 